\title{
Thyroid Gland Follicular Adenoma
}

National Cancer Institute

\section{Source}

National Cancer Institute. Thyroid Gland Follicular Adenoma. NCI Thesaurus. Code C3502.

A benign, encapsulated tumor, arising from the follicular cells of the thyroid gland. It may be associated with thyroid hormone secretion but it does not have malignant characteristics. 